\title{
ĐÁNH GIÁ HÌNH THÁI VÀ CHỨC NĂNG TÂM THU THẤT TRÁI TRÊN SIÊU ÂM TIM Ở BÊNNH NHÂN XO' GAN DO VIRUS VIÊM GAN B
}

\author{
Ngô Thị Thanh Loan ${ }^{1}$, Phạm Thị Hồng Thi², Đỗ Duy Cường ${ }^{3}$
}

TÓM TẮT.

Mục tiêu: Đánh giá môt số thông số hình thái và chức năng tâm thu (CNTTh) thất trái trên siêu âm tim ở bệnh nhân (BN) xơ gan do virus viêm gan $B$ (HBV). Đối tướng và phương pháp: Nghiên cứu mô tả, cắt ngang trên $68 \mathrm{BN}$ xơ gan do HBV Child - Pugh $B, C$ và 30 người nhóm chứng tai Trung tâm Bênh nhiệt đới và Viện Tim mạch Bệnh viện Bạch Mai tử tháng 7/2020 đển tháng 8/2021. Các thông số nghiên cứu (NC) trên siêu âm tim: Kích thước và chức năng tim trái, cung lượng tim và chỉ số Tei thất trái. Kết luận: Đường kính nhĩ trái, thất trái và khối lượng cơ thất trái ở bệnh nhân xơ gan do HBV lớn hớn so với người bình thường $(p<0.05)$. Đường kính nhĩ trái, đường kính thất trái tâm thu ở nhóm xơ gan Child - Pugh $C$ cũng lớn hơn nhóm xơ gan Child - Pugh $B(p<0.05)$. Phân suất tống máu giảm, thời gian tống máu thất trái ngắn hơn và chỉ số Tei thất trái lớn hơn ở bệnh nhân xơ gan do HBV so với người bình thường $(p<0.05)$, chỉ số Tei thất trái ở nhóm xơ gan Child - Pugh $C$ cũng lớn hơn nhóm xơ gan Child - Pugh $B(p<0,05)$. số Tei.

Tư khóa: Xơ gan; chức năng tâm thu thất trái; chì

\section{SUMMARY}

\section{EVALUATION OF MORPHOLOGY AND LEFT VENTRICULAR SYSTOLIC FUNCTION BY ECHOCARDIOGRAPHY IN PATIENTS WITH HEPATITIS B VIRUS-RELATED CIRRHOSIS}

Objjectives: To evaluate the changes of morphology and left ventricular systolic function by echocardiography in patients with hepatitis B virusrelated cirrhosis. Patients and methods: Crosssectional descriptive study was carried out on 68 HBV related cirrhotic patients and 30 matched subjects without a previous history of cardiac in Bach Mai Hospital from July 2020 to August 2021. All study participants underwent cardiac assessment with echocardiography, the parameters assessed included cardiac dimensions and left ventricular function, cardiac output, Tei index of left ventricular. Results: Left atrial diameter, left ventricular diameters, and left ventricular mass were significantly higher in the HBV related cirrhotic group $(p<0.05)$. Left atrial diameter, left ventricular end - systolic diameter were also higher in Chil - Pugh grade C group $(p<0.05)$.

${ }^{1}$ Trường Đại học y Hà Nội

${ }^{2}$ Viện tim mạch Việt Nam, Bênh viện Bạch Mai

${ }^{3}$ Trung tâm Bênh nhiệt đới, Bênh viện Bach Mai

Chiu trách nhiệm chính: Ngô Thị Thanh Loan

Email: bsngoloan@gmail.com

Ngày nhận bài: 1.7.2021

Ngày phản biên khoa học: 27.8.2021

Ngày duyệt bài: 3.9.2021
Left ventricular ejection fraction was lower, left ventricular ejection time was shorter and Tei index of left ventricular was higher in the HBV related cirrhotic group $(p<0.05)$, as well as Tei index of left ventricular was higher in Child - Pugh grade $C$ group versus Child - Pugh B group $(p<0.05)$.

Key words: Cirrhosis; left ventricular systolic function; Tei index.

\section{I. ĐĂT VẤN ĐỀ}

Nhiễm virus viêm gan $B$ (HBV) là nguyên nhân phổ biến nhất gây xơ gan ở khu vực châu Á - Thái Bình Dương. Viêt Nam thuộc vùng dich tễ lưu hành cao nhiểm HBV với tỷ lệ $10-20 \%^{1}$ và tỷ lệ xơ gan do HBV chiếm khoảng $50 \%$ số trường hợ xơ gan².

Trong 20 năm qua, người ta đã chỉ ra rằng rối loạn chức năng tim tồn tại ở những $\mathrm{BN}$ xơ gan không do rươu mà không có bênh tim đã biết và thậm chí có thể có trước các biến chứng như hội chứng gan thận ${ }^{3}$. Ở BN xơ gan, cung lượng tim tăng lúc nghỉ như một phần của tuần hoàn tăng động. Đáp ứng co cở tim có thể bị suy giảm khi gắng sức và với các thuốc tạo ra stress dược lý (bao gồm Angiotensin, isoproterenol và dobutamin) có thể là do các thụ thể $\beta$-adrenergic bị giảm nhạy cảm³ ${ }^{3}$. Ở một số BN xơ gan, tống thời gian của tâm thu cơ - điên kéo dài do kéo dài khoảng thời gian tâm thu, có thể do giảm đáp ứng với adrenergic. Dự trữ cơ tim giảm và khả năng chiết xuất oxy bi suy giảm có thể do sư mất cân bằng cục bộ trong sản xuất và chức năng của nitric oxide (NO). Cuối cùng, chức năng tâm thu xấu đi khi suy gan ngày càng tăng ${ }^{3}$.

Hiên nay ở Viêt Nam, nhiều tiến bộ trong điêu trị xơ gan đã và đang được áp dụng như tạo shunt cửa - chủ trong gan qua đường tĩnh mạch cảnh (TIPs) hoặc ghép gan nhưng những ảnh hưởng của xơ gan do HBV lên hệ tim mạch chưa thực sự được hiểu và quan tẩm NC. Vì vậy, chúng tôi tiến hành $\mathrm{NC}$ này nhằm đánh giá chức năng tâm thu thất trái trên siêu âm tim ở BN xơ gan do HBV.

\section{II. ĐỐI TƯỢNG VÀ PHƯƠNG PHÁP NGHIÊN CỨU}

Đối tượng nghiên cứu: $\mathrm{NC}$ được tiến hành trên 68 BN xơ gan do HBV (nhóm bệnh) ở giai đoạn Child - Pugh $B, C$ và 30 người khỏe mạnh (nhóm chứng) điêu trị tại Trung tâm Bệnh nhiệt đới và Viện tim mạch Bệnh viện Bạch Mai từ tháng 7/2020 đến tháng 8/2021. 
- Nhóm bệnh: Chẩn đoán xơ gan do HBV chủ yễu dựa theo các tiêu chuẩn của Tổ chức y tế Thế giới (WHO) $2015^{4}$ và Hội gan mật Châu Á Thái Bình Dương (APASL) năm 201655. BN đồng ý tham gia nghiên cứu.

Loại khỏi nhóm NC những trường hợp xơ gan do HBV có Hemoglobin $\leq 90 \mathrm{~g} / \mathrm{l}$, kèm theo ung thư biểu mô tế bào gan, đồng dương tính với HCV, HDV, HAV, HEV, HIV, có huyết khối tĩnh mạch cửa, đang có biến chứng nặng như xuất huyết tiêu hóa, đang sử dụng một số thuốc ảnh hưởng đến chức năng tim (như chẹn $\beta$ ), nghiện rượu hoặc có các bệnh lý nội - ngoại khoa kèm theo, xơ gan Child - Pugh A.

- Nhóm chứng: Không có bệnh lý nội - ngoại khoa và đồng ý tham gia nghiên cứu

Phương pháp nghiên cứu: Nghiên cứu mô tả, cắt ngang.

Tất cả BN nghiên cứu được hỏi tiền sử, khám lâm sàng và chỉ định làm xét nghiệm cần thiết để xác định hội chức suy chức năng gan và tăng áp lực tînh mạch cửa, có căn nguyên do HBV. Phân loại mức độ xơ gan theo thang điểm của Child Pugh. BN được làm siêu âm tim trên cùng hệ thống máy siểu âm tim Vivid E95 (GE) với đầu dò ma trận 2D M5Sc-D, cho phép tính toán các thông số đánh giá chức năng tim và các thông số Doppler một cách tự động. Tất cả các đối tượng nghiên cứu (nhóm bệnh, nhóm chứng) đều được thực hiện siêu âm bởi cùng một bác sĩ chuyên về siểu âm tim.

Các thông số đánh giá: đường kính nhĩ trái (LA) và thất trái (Dd, Ds); độ dày vách liên thất (IVSd); độ dày thành sau thất trái (LVPWd), khối cơ thất trái (LVM), thể tích thất trái (Vd-Vs), cung lượng tim (CO), phân suất tống máu thất trái (EF), chỉ số chức năng toàn bộ thất trái (Tei thất trái). Đo chỉ số Tei thất trái thông qua thời gian tống máu thất trái (LVET) và thời gian toàn tâm thu thất trái (MCOT). Các số liệu được thu thập theo mẫu bệnh án nghiên cứu và xử lý số liệu bằng phần mềm SPSS 16.0.

\section{KẾT QUẢ NGHIÊN CỨU}

Đặc điểm chung của nhóm nghiên cứu. Trong thời gian từ tháng $7 / 2020$ đến tháng $8 / 2021$ chúng tôi đã NC trên 68 BN Xơ gan do HBV so với 30 đối tượng ở nhóm chứng, thấy không có sự khác biệt đáng kể về tỷ lệ nam/ nữ (54/14 so với $21 / 9, p=0.31$ ) và tuổi trung bình (47.40 \pm 11.34 so với $47.30 \pm 13.80, p=0.97)$. Trong nhóm BN xơ gan do HBV, 47.1\% (32 BN) ở giai đoạn Child - Pugh B, 52.9\% (36 BN) ở giai đoạn Child - Pugh C; có $58.8 \%$ tương đương 40 $\mathrm{BN}$ có cổ trướng.

Đặc điểm hình thái, chức năng tâm thu thất trái ở bệnh nhân xơ gan do HBV

Bảng 1. Kích thước buồng tim trái và chiều dày thành thất ở 2 nhóm nghiên cứu

\begin{tabular}{|c|c|c|c|}
\hline Chỉ số & $\begin{array}{c}\text { Nhóm chứng } \\
(\mathbf{n = 3 0 )} \boldsymbol{\overline { x }} \mathbf{\pm} \text { SD }\end{array}$ & $\begin{array}{c}\text { Nhóm xo gan do HBV } \\
(\mathbf{n = 6 8 )})_{\mathbf{x}} \mathbf{\text { SD }}\end{array}$ & $\mathbf{P}$ \\
\hline LA (mm) & $27.30 \pm 3.19$ & $32.01 \pm 5.20$ & $<0.001$ \\
\hline Dd (mm) & $40.78 \pm 3.66$ & $44.83 \pm 4.43$ & $<0.001$ \\
\hline Ds (mm) & $24.83 \pm 3.84$ & $27.75 \pm 3.86$ & 0.002 \\
\hline IVSd (mm) & $7.04 \pm 1.22$ & $7.44 \pm 1.44$ & 0.19 \\
\hline LVPWd (mm) & $7.44 \pm 1.40$ & $7.77 \pm 1.27$ & 0.26 \\
\hline LVM (g) & $86.58 \pm 24.54$ & $108.06 \pm 33.87$ & 0.01 \\
\hline
\end{tabular}

Đường kính nhĩ trái, thất trái, khối cơ thất trái cao hơn đáng kế ở nhóm xơ gan gan do HBV so với nhóm chứng, sự khác biệt có ý nghĩa thống kê với độ tin cậy $99 \%$. Tuy nhiên, bề dày thành tim giữa 2 nhóm không có sự khác biệt.

Bảng 2. Chức năng tâm thu thất trái ở 2 nhóm nghiên cứu

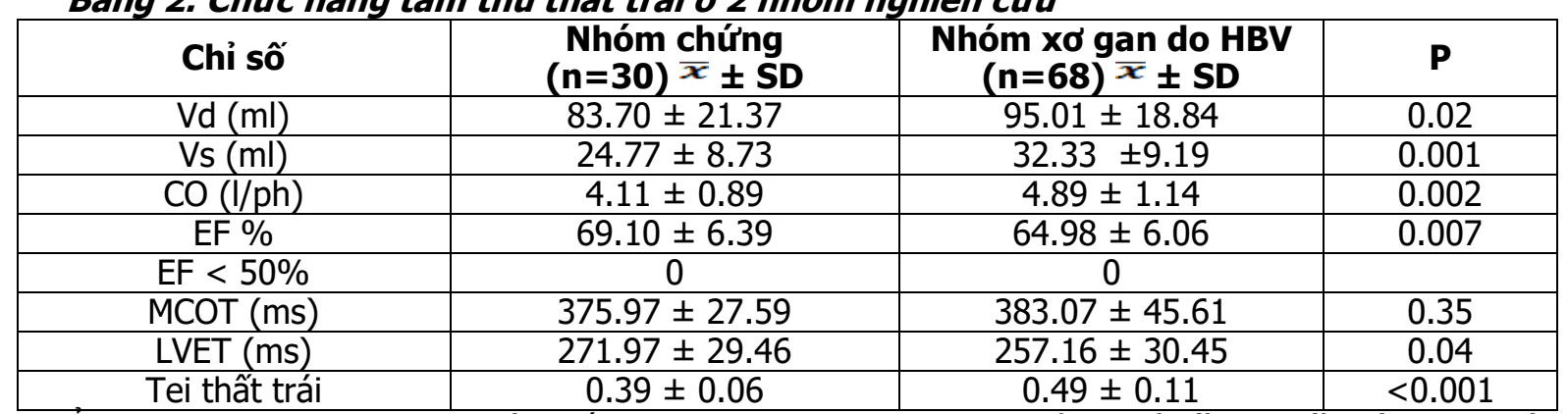

Ở BN xơ gan do HBV, LVET rút ngắn, CO tăng, Vs, Vd tăng, EF giảm, chỉ số Tei thất trái tăng khác biệt so với nhóm chứng với độ tin cậy $95 \%, 99 \%$. Không có BN xơ gan do HBV giảm EF < 50\%. 
VIETNAM MEDICAL JOURNAL N¹ - OCTOBER - 2021

Bảng 3. Kích thước buồng tim trái và chiều dày thành thất theo mức độ xơ gan do HBV

\begin{tabular}{|c|c|c|c|}
\hline \multirow[b]{2}{*}{ Chỉ số } & \multicolumn{2}{|c|}{ Mức độ xơ gan do HBV } & \multirow[b]{2}{*}{$\mathbf{P}$} \\
\hline & Child - Pugh B $(n=32)$ & Child - Pugh C $\frac{x^{x}}{ \pm \text { SD }}(n=36)$ & \\
\hline $\mathrm{LA}(\mathrm{mm})$ & $30.47 \pm 5.05$ & $33.39 \pm 5.02$ & 0.02 \\
\hline $\mathrm{Dd}(\mathrm{mm})$ & $43.93 \pm 4.19$ & $45.63 \pm 4.56$ & 0.12 \\
\hline Ds (mm) & $26.71 \pm 4.15$ & $28.67 \pm 3.38$ & 0.04 \\
\hline IVSd (mm) & $7.47 \pm 1.38$ & $7.43 \pm 1.52$ & 0.92 \\
\hline LVPWd (mm) & $7.72 \pm 1.30$ & $7.82 \pm 1.27$ & 0.74 \\
\hline $\operatorname{LVM}(\mathrm{g})$ & $104.37 \pm 31.49$ & $111.35 \pm 35.98$ & 0.40 \\
\hline
\end{tabular}

Thay đổi hình thái tim trái thấy rõ nhất ở nhóm BN xơ gan do HBV Child - Pugh C so với nhóm BN $x$ ơ gan do HBV Child - Pugh B là tăng LA, tăng Ds, $p<0.05$.

Bảng 4. Chức năng tâm thu thất trái theo giai đoạn xơ gan do HBV

\begin{tabular}{|c|c|c|c|}
\hline \multirow{2}{*}{ Chỉ số } & \multicolumn{2}{|c|}{ Giai đoạn xơ gan do HBV } & \multirow[b]{2}{*}{$\mathbf{P}$} \\
\hline & $\begin{array}{l}\text { Child - Pugh B } \\
(n=32)^{\bar{x}} \pm \text { SD }\end{array}$ & $\begin{array}{l}\text { Child - Pugh C } \\
(n=36) \\
\bar{x}\end{array}$ & \\
\hline $\mathrm{Vd}(\mathrm{ml})$ & $93.16 \pm 19.51$ & $96.66 \pm 18.36$ & 0.45 \\
\hline Vs (ml) & $30.66 \pm 9.19$ & $33.84 \pm 9.05$ & 0.16 \\
\hline $\mathrm{CO}(\mathrm{l} / \mathrm{ph})$ & $4.67 \pm 0.97$ & $5.09 \pm 1.25$ & 0.13 \\
\hline EF \% & $66.34 \pm 5.85$ & $63.78 \pm 6.07$ & 0.08 \\
\hline MCOT (ms) & $376.16 \pm 37.36$ & $397.22 \pm 48.04$ & 0.006 \\
\hline LVET (ms) & $251.56 \pm 29.42$ & $262.14 \pm 30.89$ & 0.15 \\
\hline Tei thất trái & $0.46 \pm 0.10$ & $0.52 \pm 0.11$ & 0.03 \\
\hline
\end{tabular}

Thời gian toàn tâm thu thất trái (MCOT), Chỉ số Tei thất trái ở nhóm xơ gan do HBV Child Pugh $C$ tăng cao hơn so với nhóm xơ gan do HBV child -Pugh B, sự khác biệt có ý nghĩa thống kê với độ tin cậy $95-99 \%$. Không thấy khác biệt giữa các thông số $\mathrm{CO}, \mathrm{Vd}, \mathrm{Vs}, \mathrm{EF}$, LVET giữa 2 nhóm xơ gan do HBV theo mức độ xơ gan.

\section{BÀN LUẬN}

Hầu hết các NC đánh giá thay đổi hình thái tim ở BN xơ gan do HBV đều thống nhất kết quả là LA tăng rõ 6 , kết quả của chúng tôi cũng ghi nhận tương tự như vậy.

Một số thổng sỗ đánh giá hình thái tim khác thì chưa thống nhất kết quả giữa các NC. Trong NC của chúng tôi, ở BN xơ gan do HBV so với nhóm chứng thấy tăng $\mathrm{Dd}, \mathrm{p}<0.001$; tăng $\mathrm{Ds}$, $p=0.002$; tăng LVM, $p=0.01$, bảng 1 . Khác với NC của chúng tôi, Yuan W và CS (2019) trên 79 $B N$ xơ gan do HBV so với 103 BN viêm gan $B$ mạn tính, thấy tăng rõ $\mathrm{Ds}, \mathrm{p}=0.007$, nhưng không thay đổi đáng kể Dd, IVSd, LVPWd'.

Không chỉ thay đổi hình thái tim, CNTTh thất trái ở BN xơ gan do HBV khi nghỉ cũng bị ảnh hưởng. Nhóm BN xơ gan do HBV tăng rõ cung lượng tim (4.89 \pm 1.14 so với $4.11 \pm 0.89$ lít/ph, $\mathrm{p}=0.002)$. Đây chính là những dấu hiệu thể hiện tình trạng tuần hoàn tăng động ở $\mathrm{BN} x$ ơ gan. Trong NC, chúng tôi nhận thấy phân suất tông máu thất trái (EF) ở BN xơ gan do HBV giảm so với nhóm chứng $(64.98 \pm 6.06$ so với
$69.10 \pm 6.39 \%, \mathrm{p}=0.007)$ nhưng vẫn trong giới hạn bình thường. Nghiên cứu của Abd-El-Aziz T.A và CS $(2010)^{6}$ cũng cho thấy $E F$ thất trái ở $\mathrm{BN}$ xơ gan giảm nhe hơn so với nhóm chứng. Ở $\mathrm{BN}$ xơ gan EF thất trái bình thường khi nghỉ, tuy nhiên thực tế dự trữ co cơ tim đã giảm đáng kể, tình trạng suy tim thực thụ bộc lộ khi gắng sức hoặc can thiệp điều trị, từ đó có thể gây ra những biến cố bất lợi cho người bệnh.

Về chỉ số Tei thất trái chúng tôi nhận thấy ở nhóm bệnh có sự rút ngắn LVET hởn so với nhóm chứng, $\mathrm{p}=0.04$; có sự kéo dài MCOT hơn nhưng $p>0.05$; chỉ số Tei thất trái lớn hơn, $p<$ 0.001 . Tương tự như kết quả NC của Abd-El-Aziz T.A. và CS (2010) ${ }^{6}$.

Chỉ số Tei có thể phản ánh được chức năng toàn bộ thất, không phụ thuộc và̀o hình dạng thất và ít bị ảnh hưởng bởi nhịp tim, huyết áp và tiền gánh. Ở $\mathrm{BN}$ xơ gan thường có tần số tim tăng (tuần hoàn tăng động) và tiền gánh giảm nên chỉ số Tei tăng ở nhóm BN này chính là biểu hiện của rối loạn chức năng tim. Cơ chế lý giải là do cường Aldosterone thứ phát dẫn tới loạn dưỡng, phì đại tế bào cơ tim, xơ hóa tổ chức kẽ, từ đó làm co cứng cơ thất và giảm khả năng chun giãn đàn hồi. Cơ tim cần một thời gian thư giãn dài hơn để đảm bảo đây máu thất và duy trì áp lực cuối tâm trương thất trái (kéo dài IVRT), kéo dài thời gian toàn tâm thu thất trái, đồng thời co bóp của tế bào cơ tim cũng bị ảnh hưởng không duy trì được một áp lực tống máu đủ dài 
(rút ngắn thời gian tống máu). Rút ngắn thời gian tống máu phản ánh gián tiếp sự giảm co bóp cơ tim.

NC của chúng tôi đánh giá thay đổi hình thái giữa 2 nhóm xơ gan theo thang điểm Child Pugh thu được kết quả tăng LA, tăng Ds ở nhóm xơ gan Child - Pugh $C$ hơn so với nhóm xơ gan Child - Pugh $B, p<0.05$; EF giảm hơn ở nhóm xơ gan Child Pugh $C$, nhưng mức giảm nhẹ, không có ý nghĩa thống kê. Không có sự khác biệt vể Vd, CO giữa 2 nhóm. MCOT kéo dài, chỉ số Tei thất trái tăng hơn ở nhóm xơ gan Child - Pugh $\mathrm{C}$ so với nhóm xơ gan Child - Pugh $B, p<0.05$.

Nhiều NC cũng cho kết quả CNTTh thất trái ở $B N$ xơ gan luôn được bảo tồn khi nghỉ dù $B N$ ở giai đoạn xơ gan nhẹ hay nặng. Abd-El-Aziz và CS (2010) thấy tăng dần LA rõ theo mức độ xơ gan Child Pugh, $\mathrm{p}<0.05$, nhưng không thấy sự khác biệt về CO, EF\%, chỉ số Tei thất trái ${ }^{6}$. Yuan W và CS (2019) không thây sự khác biệt về Dd thất trái, độ dày thành thất, $\mathrm{EF}$ thất trái giữa các mức độ xơ gan?.

\section{KẾT LUÂN}

- Đường kính nhĩ trái, thất trái và khối lượng cơ thất trái ở bệnh nhân xơ gan do HBV lớn hơn so với người bình thường $(p<0.05)$. Đường kính nhĩ trái, đường kính thất trái tâm thu ở nhóm xơ gan Child - Pugh $C$ cũng lớn hơn nhóm xơ gan Child - Pugh B $(p<0,05)$.
- Phân suất tống máu giảm, thời gian tống máu thất trái rút ngắn, chỉ số Tei thất trái lớn hơn ở bệnh nhân xơ gan do HBV so với người bình thường $(p<0.05)$ và chỉ số Tei thất trái ở nhóm xơ gan Child - Pugh $C$ cũng lớn hơn nhóm $x \sigma$ gan Child - Pugh $B(p<0,05)$.

\section{TÀI LIẸU THAM KHẢO}

1. Nguyen VTT (2012). Hepatts B infecton in Vietnam: Current Issues and Future Challenges. AsiaPacifc Journal of Public Health; 24(2): 361-373.

2. Trân Văn Huy, Nguyến Thị Huyên Thương (2016). Nghiên cứu hiệu quả của tenofovir trên bệnh nhân xơ gan do virus viêm gan $B$. Tạp chí $Y$ Dước hoc - Trường Đai hoc Y Dước Huế; 32: 25-29.

3. Heintz K., Hollenberg S.M. (2018). Circulatory Physiology in Liver Disease. In: Nanchal R., Subramanian R. (eds). Hepatic Critical Care; Springer, Cham. https://doi.org/10.1007/978-3319-66432-3 2

4. World Health Organization (2015). Guidelines for the Prevention, Care and Treatment of Persons with Chronic Hepatitis B Infection. Pp. 1-166.

5. Sarin, S. K., Kumar, M., Lau, et al (2016). Asian-Pacific clinical practice guidelines on the management of hepatitis B: a 2015 update. Hepatology international, 10(1), 1-98. https://doi.org/10.1007/s12072-015-9675-4

6. Abd-El-Aziz T.A., Abdou M., Fathy A., et al. (2010). Evaluation of Cardiac Function in Patients with Liver Cirrhosis. Intern Med; (49), pp. 2547-2552.

7. Yuan W., Lu, H. Z., Mei, X., et al (2019). Cardiac health in patients with hepatitis B virusrelated cirrhosis. Medicine; 98(13), e14961. https://doi.org/10.1097/MD.0000000000014961

\section{ĐÁNH GIÁ HIỆU QUẢ CỦA LACTULOSE ĐƯờNG THỤT TRONG ĐIỀU TRI BỆNH NÃO GAN Ở BỆNH NHÂN XƠ GAN}

\section{TÓM TẮT}

Mục tiêu: Theo dõi đáp ứng lâm sàng và các biểu hiện cận lâm sàng của bệnh nhẩn xơ gan có hội chứng não gan với lactulose đường thụt. Đối tượng và phương pháp: Tổng số 32 bênh nhân chẩn đoản có biểu hiện tiền hôn mê gan được được đánh giá theo thang điểm West Haven, điểu trị bằng sử dung lactulose đường thụt hậu môn. Kết quả: Tỷ lệ bệnh nhân cải thiện nồng độ $\mathrm{NH} 3$ gặp ở 84,4\% bệnh nhân có cải thiện phân mức nồng độ NH3 máu, 15,6\% không cải thiện. Trạng thái tinh thần cải thiện ở

${ }^{1}$ Trung tâm tiêu hóa gan mật, Bệnh viện Bạch mai Bệnh viên $E$ trung ương

Chịu trách nhiệm chính: Nguyễn Công Long

Email: nguyenconglongbvbm@gmail.com

Ngày nhân bài: 2.7.2021

Ngày phản biên khoa hoc: 27.8.2021

Ngày duyệt bài: 3.9.2021

\section{Nguyễn Công Long1, Đào Văn Thành ${ }^{2}$}

$53,1 \%$ bệnh nhân. Theo mức độ nặng của hội chứng não gan theo phân loại West Haven $53,1 \%$ bệnh nhân có cải thiện. Kết luận: Lactulose đường thụt hậu môn có hiệu quả cải thiên nồng độ NH3 trong máu và triêu chứng lâm sàng đối với bệnh nhân có hội chứng nã̃o gan.

Tứ khoá: Lactulose; bệnh não gan; xơ gan

\section{SUMMARY}

\section{EVALUATION OF THERAPEUTIC OF EFFECTIVENESS OF LACTULOSE ENEMA IN HEPATIC ENCEPHALOPATHY}

Objective: We aimed to determine the effect of lactulose enema for treatment hepatic encephalopathy patients base on clinical and laboratory parameters. Subjects and methods: A total of 32 patients with hepatic encephalopathy treated with lactulose enema, West Haven Criteria was applied. Results: For overall response rate of the 32 patients who underwent 